\title{
Weed Dynamics in Rejuvenated Robusta Coffee Plantation of Jorhat District of Assam, India
}

\author{
A.R. Bora ${ }^{1}$, J. Deka ${ }^{2}$ and I.C. Barua ${ }^{2}$ \\ ${ }^{1}$ Regional Coffee Research Station, Diphu, Assam- 782 460, India \\ ${ }^{2}$ Assam Agricultural University, Jorhat, Assam- 785 013, India \\ *Corresponding author
}

\section{Keywords}

Weed dynamics, Coffee plantation, Borreria articularis

Article Info

Accepted:

10 March 2019

Available Online:

10 April 2019

\section{A B S T R A C T}

Weed problems are very complex and serious in coffee plantations of North East Region of India because of favourable agro climatic situations for weed growth. The study on emergence and population dynamics of weeds will help to develop efficient weed management strategy. Therefore, the present investigation was undertaken for two consecutive years in 2016 and 2017 at the Experimental Garden for Plantation Crops of Assam Agricultural University, Jorhat, Assam with the objective to study the weed dynamics in rejuvenated robusa coffee. In soil seed bank study, the weed emergence was recorded in decreasing order of Borreria articularis, Sporobolus sp, Ageratum hostonianu, Isachne globosa, Mikania micrantha, Polygonum sp, Diplezium esculentum and Digitaria setigera. The weeds present in rejuvenated coffee consisted of two species of grasses, one species of sedge and six species of broad leaf weeds. Among the grassy weeds, Isachne globosa and Sporobolus sp. were the dominant ones. The only sedge present was Cyperus iria. The predominant among broad leaf weeds were Mikania micrantha, Gynura bicolor, Spermacoce hispida and Scoparia dulcis. The weed dynamics revealed the peak density of grass, sedge and broad leaf weed at 80, 120 and 80-160 days after manual weeding and thereafter showed a decreasing trend.

\section{Introduction}

Coffee is one of the most important plantation crops of India. In North East India, coffee cultivation is confined in the states of Arunachal Pradesh, Assam, Manipur, Meghalaya, Mizoram, Nagaland and Tripura covering 8012 ha providing benefit to more than 11,000 families (Anonymous, 2018). The North East Region of India is a biological hotspot and harbours exceptional biodiversity and has relatively complex biogeography. In this region, weed problems are very complex and serious in coffee plantations because of favourable agro climatic situations for weed growth. A number of weed associations compete with coffee from seedling to harvesting stage for water, light and mineral nutrients. In rejuvenated coffee plantations, weeds are a serious problem particularly during the first three years till the canopy of the coffee plant develops. Weed hinders 
growth of rejuvenated coffee plants and may cause mortality. Free growth of weeds reduced the yield of coffee by over $50 \%$ in Kenya (Nyabundi and Kimemia, 1998).

The weed succession and distribution patterns in coffee estate are dynamic in nature. Composition of the weed flora may differ depending on location (Hussain et al., 2008). The study of emergence behaviour and population dynamics of weeds will generates useful information to develop efficient weed management strategy. (Deka et al., 2016)

However, information on the emergence, composition, abundance, and dynamics of weed species in rejuvenated robusta coffee plantations of North East Region of India is lacking. Keeping in view the above facts, the present investigation was undertaken at Assam Agricultural University, Jorhat with the objective to study the emergence, dynamics and the changes in dominance spectrum of weeds in rejuvenated robusta coffee.

\section{Materials and Methods}

Soil seed bank study was conducted at the Department of Agronomy, AAU, Jorhat. From the rejuvenated coffee plot of the Experimental Garden for Plantation Crops, AAU, Jorhat soil samples were collected up to a depth of $10 \mathrm{~cm}$ during the month of February, 2017 and bulked. From the bulked sample 3 sub sample were prepared. These soils were spread at a depth of $10 \mathrm{~cm}$ on thermocol trays of size $40 \mathrm{~cm}$ x $30 \mathrm{~cm}$. Holes were made on the bottom of the trays for draining of excess water. The trays were kept in net house to prevent contamination from air borne seeds. Tap water, free of weed seed contamination, was regularly sprinkled to keep the soil of the trays moist. All the emerged weeds were allowed to grow to four leaf stages and after counting the population of the recognised weed species, respective plants were eradicated from the trays. The data recording followed by eradication of the weeds at the recognisable state were continued for the entire year as the season bound weed species emerged at different times. However, no chemical was sprayed to break the dormancy of soil borne seeds. The data was recorded from May 2017 to January 2018.

After receipt of pre-monsoon shower during the month of April, manual weeding was carried out and FYM was applied to the experimental plot. To record the composition, abundance, and dynamics, the weed population was counted individually from the rejuvenated coffee plot in 2016 and 2017 (From $15^{\text {th }}$ May to $22^{\text {th }}$ October) at 40 days interval using a quadrate of $50 \mathrm{~cm} \times 50 \mathrm{~cm}$ size and expressed as numbers per one square meter size. The total weed population, the population of dominated weeds was observed critically.

\section{Results and Discussion}

\section{Weed seed bank study}

A total of 11 numbers of weeds were recorded to emerge from the seed bank of rejuvenated coffee soil (Table 1).

\section{Weed flora}

The $M$. micrantha associated weeds in rejuvenated coffee consisted of two species of grasses, one species of sedge and five species of broad leaf weeds (Table 2). Among the grassy weeds, Isachne globosa (Thunb.) Kuntze and Sporobolus sp. were the dominant ones. The only sedge present was Cyperus iria L. The predominant among broad leaf weeds were Gynura bicolor (Roxb.ex. Willd.) DC, Spermacoce hispida L. and Scoparia dulcis L. 
Table.1 Soil weed seed bank study of rejuvenated coffee eco system

\begin{tabular}{|c|c|c|c|c|}
\hline \multirow[t]{2}{*}{ Name of the weed } & \multicolumn{4}{|c|}{ Weed emergence from $40 \mathrm{~cm} \times 30 \mathrm{~cm} \times 10 \mathrm{~cm}\left(12000 \mathrm{~cm}^{3}\right)$ soil } \\
\hline & May, 2017 & Sep, 2017 & Jan, 2018 & Total \\
\hline Spermacoce hispida $\mathrm{L}$. & 68.7 & 12.3 & 3.0 & 84.0 \\
\hline Sporobolus sp. & 3.6 & 12.2 & 1.7 & 17.5 \\
\hline Ageratum houstonianum (Mill) & 0 & 6.7 & 1.7 & 8.4 \\
\hline Isachne globosa (Thunb.) Kuntze & 0 & 2.7 & 5.3 & 8.0 \\
\hline Mikania micrantha H.B.K. & 3.7 & 2.3 & 1.0 & 6.0 \\
\hline Scoparia dulcis $\mathbf{L}$ & 0 & 1.3 & 0 & 1.3 \\
\hline Melastoma malabathricum $L$. & 0 & 0.3 & 0.3 & 0.6 \\
\hline $\begin{array}{l}\text { Alternanthera sessilis (L.) R. Br.ex } \\
\text { DC. }\end{array}$ & 0 & 0.3 & 0 & 0.3 \\
\hline Polygonum sp & 0 & 1.0 & 2.3 & 3.3 \\
\hline Impatiens balsamina (L.) & 0 & 0.7 & 0 & 0.7 \\
\hline Diplezium esculentum (Retz.) Sw & 0 & 0 & 2.3 & 2.3 \\
\hline Digitaria setigera Roth & 0.7 & 0.7 & 0 & 1.4 \\
\hline Cyperus rotandus (L.) & 0.3 & 0 & 0 & 0.3 \\
\hline
\end{tabular}

Table.2 M. micrantha associated weed in rejuvenated coffee at AAU, Jorhat

\begin{tabular}{|c|c|c|c|c|}
\hline Botanical name & Family & Habit & Common name & $\begin{array}{c}\text { Vernacular } \\
\text { name } \\
\text { (Assamese) }\end{array}$ \\
\hline \multicolumn{5}{|l|}{ A. Grass weeds } \\
\hline $\begin{array}{l}\text { Isachne globosa (Thunb.) } \\
\text { Kuntze* }\end{array}$ & Poaceae & $P$ & Swamp millet & Horu bahpotia \\
\hline Sporobolus sp.* & Poaceae & $\mathrm{P}$ & Smut grass & Topaholi \\
\hline \multicolumn{5}{|l|}{ B. Sedge weeds } \\
\hline Cyperus iria $\mathrm{L}$. & Cyperaceae & A & Yellow nut sedge & Murphula bon \\
\hline \multicolumn{5}{|l|}{ C. Broad leaved weeds } \\
\hline $\begin{array}{l}\text { Merremia umbellate } \mathrm{L} \text {. } \\
\text { Hallier f. }\end{array}$ & Convolvulaceae & $\mathrm{P}$ & Hogvine & Kalia lata \\
\hline $\begin{array}{l}\text { Mikania micrantha } \\
\text { (HBK)* }\end{array}$ & Asteraceae & $\mathrm{P}$ & Bitter vine & Japani lota \\
\hline $\begin{array}{l}\text { Gynura bicolor (Roxb. ex. } \\
\text { Willd.) DC** }\end{array}$ & Asteraceae & A & Velvet plant & Kopahibon \\
\hline Spermacoce hispida $\mathrm{L} . *$ & Rubiaceae & A & Button weed & Gahoribon \\
\hline Scoparia dulcis L.* & Scrophulariaceae & A & Broom weed & Bondhonia \\
\hline Mimosa pudica $\mathrm{L}$. & Mimosaceae & A & Touch-me-not & Nilajibon \\
\hline
\end{tabular}


Table.3 Population dynamics of different weeds (Nos. m-2) in rejuvenated coffee at different days after manual weeding

\begin{tabular}{|c|c|c|c|c|}
\hline Botanical name & 40 DAMW & 80 DAMW & 120 DAMW & 160 DAMW \\
\hline \multicolumn{5}{|c|}{2016} \\
\hline $\begin{array}{l}\text { Isachne globosa } \\
\text { (Thunb.) Kuntze }\end{array}$ & 17.35 & 56.38 & 35.67 & 9.60 \\
\hline Sporobolus sp & 2.25 & 6.67 & 5.05 & 3.80 \\
\hline Cyperus iria L. & 1.36 & 3.67 & 5.26 & 4.33 \\
\hline $\begin{array}{l}\text { Merremia umbellate L. } \\
\text { Hallier f. }\end{array}$ & 1.25 & 1.65 & 3.04 & 1.14 \\
\hline $\begin{array}{l}\text { Mikania micrantha } \\
\text { (HBK) }\end{array}$ & 3.0 & 6.15 & 5.67 & 4.00 \\
\hline $\begin{array}{l}\text { Gynura bicolor } \\
\text { (Roxb. ex . Willd.) DC }\end{array}$ & 2.38 & 5.50 & 7.46 & 8.00 \\
\hline Spermacoce hispida L. & 2.76 & 4.45 & 18.38 & 13.76 \\
\hline Scoparia dulcis L. & 0 & 3.30 & 5.14 & 8.33 \\
\hline Mimosa pudica $\mathbf{L}$. & 0 & 3.68 & 6.00 & 3.33 \\
\hline \multicolumn{5}{|c|}{2017} \\
\hline $\begin{array}{l}\text { Isachne globosa } \\
\text { (Thunb.) Kuntze }\end{array}$ & 4.37 & 65.2 & 43.06 & 7.81 \\
\hline Sporobolus sp & 0.26 & 5.45 & 4.3 & 2.06 \\
\hline Cyperus iria $\mathrm{L}$. & 1.00 & 2.82 & 4.50 & 2.60 \\
\hline $\begin{array}{l}\text { Merremia umbellate } \mathrm{L} \text {. } \\
\text { Hallier f. }\end{array}$ & 0.09 & 0.74 & 2.30 & 0.85 \\
\hline $\begin{array}{l}\text { Mikania micrantha } \\
\text { (HBK) }\end{array}$ & 3.67 & 5.68 & 5.33 & 4.68 \\
\hline $\begin{array}{l}\text { Gynura bicolor } \\
\text { (Roxb. ex . Willd.) DC }\end{array}$ & 0.72 & 2.59 & 6.29 & 9.07 \\
\hline Spermacoce hispida L. & 0 & 4.06 & 13.14 & 24.60 \\
\hline Scoparia dulcis L. & 0 & 0.93 & 7.84 & 15.20 \\
\hline Mimosa pudica L. & 0 & 2.14 & 6.40 & 2.96 \\
\hline
\end{tabular}

Note: days after manual weeding

\section{Weed dynamics}

The data (Table 3) during 2016 and 2017 revealed that the density of grass weeds increased from 40 days after weeding up to 80 days after weeding and thereafter it decreased up to 160 days after weeding. The sedge density increased from 40 days after weeding up to 120 days after weeding and thereafter it decreased up to 160 days after weeding. In case of different broadleaf weeds, density increased from 40 days after weeding or 80 days after weeding and reached peak at 80 or 120 or 160 days after weeding and thereafter decreased.

\section{References}

Anonymous 2018. Coffee Board North Eastern Region, Annual report for the year 2017-18, Joint Director (E), North Eastern Region, Guwahati, pp 22-24. 
Deka, J., Kakati, P and Barua, I.C. 2016. Weed dynamics in direct seeded autumn rice- transplanted winter rice sequence. International Journal of Science, Environment and Technology 5 (6): $4179-4185$

Hussain, S., Ramzan, M., Akhter, M.and Aslam, M. 2008. Weed management in direct seeded rice. The J. Anim. and
Plant Sci. 18: 86-88.

Langthasa, P and Bora A. R. 2013. Coffee in the North eastern region- Profile of coffee in 7 sisters, Joint Director (E), North Eastern Region, Guwahati. 2 pp. Nyabundi K. W. and Kimemia, J. K. 1998. Difficult weeds in Kenya coffee. Kenya coffee Review 63: 49.

\section{How to cite this article:}

Bora, A.R., J. Deka and Barua, I.C. 2019. Weed Dynamics in Rejuvenated Robusta Coffee Plantation of Jorhat District of Assam, India. Int.J.Curr.Microbiol.App.Sci. 8(04): 895-899. doi: https://doi.org/10.20546/ijcmas.2019.804.102 